\title{
Enrichment and Cultivation of Denitrifying Phosphorus Removing Bacteria
}

\author{
Jinlan Lian ${ }^{1, a}$, Xing $\operatorname{Jin}^{2, b^{*}}$ \\ ${ }^{1}$ School of Resources and Environmental Engineering,Jilin Institute of Chemical Technology , \\ China \\ ${ }^{2}$ School of Chemical and Pharmaceutical Engineering, Jilin Institute of Chemical Technology, China \\ a lianjinlan@sina.com, ${ }^{\mathrm{b}}$ jinxing70@sina.com
}

Keywords: SBR; Enrichment; Cultivation; DPB

Abstract. The denitrifying phosphorus removal bacteria (DPB) were enrichment using SBR reactor and two stages of training method under the low carbon source with nitrate as electron acceptor. The system was operated under the condition of anaerobic-aerobic-precipitation-discharge for 10 cycles in the first stage, and the condition of anaerobic-aerobic-anoxic-aerobic -precipitation-discharge were used for 40 cycles in the second stage. Results showed removal rate of $\mathrm{PO}_{4}{ }^{3-}-\mathrm{P}, \mathrm{NH}_{4}{ }^{+}-\mathrm{N}$ and COD was $95 \%, 80 \%$ and $90 \%$ when the effluent concentration was below $0.4 \mathrm{mg} / \mathrm{L}, 3 \mathrm{mg} / \mathrm{L}$ and $20 \mathrm{mg} / \mathrm{L}$ respectively, which indicated that enrichment and cultivation of DPB in a set of SBR was feasible.

\section{Introduction}

Denitrifying phosphorus removing bacteria (DPB) can denitrify nitrogen and remove phosphorus at the same time in anoxia condition, using oxygen, nitrite and nitrate as electron acceptor[1]. The character of DPB can successfully solve the carbon source problem and competition problem of various bacterium genus in the process of denitrification and dephosphorization. The carbon source has two functions what can effectively solve the contradiction of sludge age, carbon source and nitration and phosphorus removal, release and absorption; furthermore, it has the advantage of saving the amount of aeration and reducing the production of sludge[2-3].

In this study the backflow sludge in the A/O process were used as the sludge sample which collected from an urban sewage treatment plant in a certain city. SBR reactor were used and took the nitrate as electron acceptor to enrichment culture DPB with a low carbon source and investigated the performance of synchronal denitrification and dephosphorization.

\section{Experiment}

\section{Equipment and procedure}

The SBR reactor in time sequence were used in this experiment as the equipment of DPB cultivation . It is with a diameter of $30 \mathrm{~cm}$, a height of $40 \mathrm{~cm}$, a volume of $25 \mathrm{~L}$ and an escape pipe which can discharge sludge in the bottom of the reactor. The instantly influent water were used, and the amount of influent water in one cycle were 19 20L. In the anaerobic and anoxia condition, the mechanical stirrer were used to keep the sludge suspended and uniform, and the temperature is controlled at $30^{\circ} \mathrm{C}$. In the anoxia stage, the potassium nitrate solution with different concentration was added according to the need, which would be used as the electron acceptor needed in the reaction.

\section{The project and method of analysis}

Waste water samples after centrifuge was analyzed by the state standard method. The analysis project and method were shown in Table 1. 
Table 1 . The project and method of analysis

\begin{tabular}{c|l}
\hline project & \multicolumn{1}{c}{ method } \\
\hline $\mathrm{COD}_{\text {cr }}$ & Potassium dichromate method \\
\hline $\mathrm{NH}_{4}{ }^{+}-\mathrm{N}$ & Na 's reagent spectrophotometric method \\
\hline $\mathrm{NO}_{3}{ }^{-}-\mathrm{N}$ & Thymol Spectrophotometry \\
\hline $\mathrm{NO}_{2}{ }^{-}-\mathrm{N}$ & $\mathrm{N}$ - (1 - naphthyl ) B two amine photometric method \\
\hline $\mathrm{PO}_{4}{ }^{3-}-\mathrm{P}$ & Molybdenum antimony anti - spectrophotometric method \\
\hline $\mathrm{MLSS}$ & Gravimetric method \\
\hline
\end{tabular}

\section{The main reagent}

Sludge culture fluid were prepared by artificial simulation of low carbon city sewage, and added ethanol, $\mathrm{NH}_{4} \mathrm{Cl}$ and $\mathrm{KH}_{2} \mathrm{PO}_{4}$ to it for obtaining a certain concentration of $\mathrm{COD}, \mathrm{NH}_{4}{ }^{+}-\mathrm{N}$ and $\mathrm{PO}_{4}{ }^{3-}-\mathrm{P}$. And added $\mathrm{CaO} 0.014 \mathrm{~g} / \mathrm{L} ; \mathrm{KI} 0.030 \mathrm{~g} / \mathrm{L} ; \mathrm{MgCl}_{2} 0.040 \mathrm{~g} / \mathrm{L} ; \mathrm{ZnSO}_{4} 0.050 \mathrm{~g} / \mathrm{L} ; \mathrm{CuSO}_{4} 0.016 \mathrm{~g} / \mathrm{L}$; $\mathrm{CoCl}_{2} 0.005 \mathrm{~g} / \mathrm{L} ; \mathrm{AlCl}_{3} 0.010 \mathrm{~g} / \mathrm{L} ; \mathrm{FeSO}_{4} 0.050 \mathrm{~g} / \mathrm{L} ;$ EDTA $0.001 \mathrm{~g} / \mathrm{L} ; \mathrm{SnCl}_{2} 0.001 \mathrm{~g} / \mathrm{L} ; \mathrm{NaNO}_{3}$ $0.040 \mathrm{~g} / \mathrm{L}$ to the water. The water quality were shown in Table 2 .

Table 2. The quality of raw water

\begin{tabular}{c|c|c|c|c}
\hline Parameter & $\mathrm{COD}(\mathrm{mg} / \mathrm{L})$ & $\mathrm{NH}_{4}{ }^{+}-\mathrm{N}(\mathrm{mg} / \mathrm{L})$ & $\mathrm{PO}_{4}{ }^{3-}-\mathrm{P}(\mathrm{mg} / \mathrm{L})$ & $\mathrm{PH}$ \\
\hline value & 150 & 50 & 10 & $7-8$ \\
\hline
\end{tabular}

\section{Enrichment and cultivation of DPB}

This study took the backflow sludge in the $\mathrm{A} / \mathrm{O}$ process as the experiment sludge which was collected from an urban sewage treatment plant in a certain city, and the cultivation and domestication of DPB were divided into two stages. The first stage used the operation mode of anaerobic/anoxia and had 10 operation cycles. The second stage used the operation mode of anaerobic/aerobic/anoxia/aerobic and had 40 operation cycles. Gradually increase the anaerobic and lack of oxygen during the operation of time, gradually reduce the aerobic time. The details were shown in Table 3, the SBR operation mode.

Table 3. The SBR operation mode

\begin{tabular}{c|c|c|c|c|c}
\hline \multirow{2}{*}{$\begin{array}{c}\text { operation } \\
\text { stage }\end{array}$} & Cycles & \multicolumn{5}{|c}{ Time (h) } \\
\cline { 3 - 6 } & & anaerobic & anaerobic & anaerobic & anaerobic \\
\hline First stage & 10 & 3 & 3 & - & - \\
\hline Second stage & 40 & $2.5 \sim 3$ & $1.5 \sim 0$ & $1.5 \sim 4$ & $0.5 \sim 0$ \\
\hline
\end{tabular}

The first stage is the cultivation and domestication of $\mathrm{PAO}_{\mathrm{S}}$, uses the operation mode of anaerobic $3 \mathrm{~h} /$ aerobic $3 \mathrm{~h} /$ precipitation $0.5 \mathrm{~h} /$ drainage $0.5 \mathrm{~h}$ and has 10 operation cycles. The details were shown in Table 3, the SBR operation mode. In the cultivation course of this stage, the DO of anaerobic stage and aerobic stage are $0.03-0.2 \mathrm{mg} / \mathrm{L}$ and $2-4 \mathrm{mg} / \mathrm{L}$, respectively. The influent $\mathrm{COD}, \mathrm{PO}_{4}{ }^{3-}-\mathrm{P}$ and $\mathrm{MLSS}$ are controlled at about $150 \mathrm{mg} / \mathrm{L}, 10 \mathrm{mg} / \mathrm{L}$ and $3000 \mathrm{mg} / \mathrm{L}$, respectively. The concentration of $\mathrm{PO}_{4}{ }^{3-}-\mathrm{P}$ in every period were shown in Fig.2.

The second stage is the enrichment of DPB phosphorus removal bacteria. Under the operation mode of anaerobic/aerobic/anoxia/aerobic/precipitation/drainage, gradually reduce the aerobic operation time while extend the anoxic and anaerobic operation time and increase the amount of nitrates added. It has 40 operation cycles and the details were shown in Table 3, SBR operation mode. The DO concentration of the anaerobic stage, aerobic stage and anoxia stage were $0.03-0.2 \mathrm{mg} / \mathrm{L}, 2-4 \mathrm{mg} / \mathrm{L}$ and 0.2-0.5 mg/L, respectively. The influent COD, $\mathrm{PO}_{4}{ }^{3-}-\mathrm{P}$ and MLSS concentration were maintained at 
about $150 \mathrm{mg} / \mathrm{L}, 10 \mathrm{mg} / \mathrm{L}$ and $3000 \mathrm{mg} / \mathrm{L}$, respectively. The amount of $\mathrm{NO}_{3}{ }^{-}-\mathrm{N}$ and anhydrous sodium sulfite concentration added were $40 \mathrm{mg} / \mathrm{L}$ and $5 \mathrm{mg} / \mathrm{L}$, respectively.

The conventional enrichment method of DPB phosphorus removal bacteria were A/A/O operation mode. This method were beneficial to the sufficient absorption of phosphorus in the aerobic stage. However, in the course of the experiment, it was found that if the rbCOD in the anoxia stage was too high, the denitrifying process occurred easily. So this experiment used the opposite process of the conventional $\mathrm{A} / \mathrm{A} / \mathrm{O}$ operation mode, namely, $\mathrm{A} / \mathrm{O} / \mathrm{A}$ operation mode. It effectively ensured the beneficial condition of denitrifying process, but it was found in the course of experiment that this method had a great influence on the phosphorus removal process in the next cycle. In order to solve the problem, we increased the short time aeration after the anoxia stage,the aerobic run. It not only effectively absorbed the surplus phosphorus, but also improved the settling performance of sludge.

\section{Results and discussion}

\section{Analysis of the enrichment and cultivation of DPB}

Figure 1 shows the change of $\mathrm{PO}_{4}{ }^{3-}-\mathrm{P}$ concentration in the first stage. From Figure 1 , we can see that the concentration of effluent $\mathrm{PO}_{4}{ }^{3-}-\mathrm{P}$ reached $0.4 \mathrm{mg} / \mathrm{L}$ with removal of $95.8 \%$, and the COD removal were found to be more than $90 \%$. after the cultivation and domestication in the first stage. Because the seed sludge was collected from the backflow sludge in the $\mathrm{A} / \mathrm{O}$ process, there was a rich content of PAOs in it. Trained after 10 cycles, PAOs can operate steadily in the system. With the seed sludge adapted to the new living environment, taken 7 cycles, effluent TP can achieve below 1mg/L. The aerobic absorption of phosphorus content is twice as anaerobic phosphorus release. It can consumed $10 \mathrm{mg}$ COD when released $1 \mathrm{mg}$ P, which is closed to the "7-10 $\mathrm{mg}$ acetate is about to remove $1 \mathrm{mg}$ P” pointed out by Wentze.

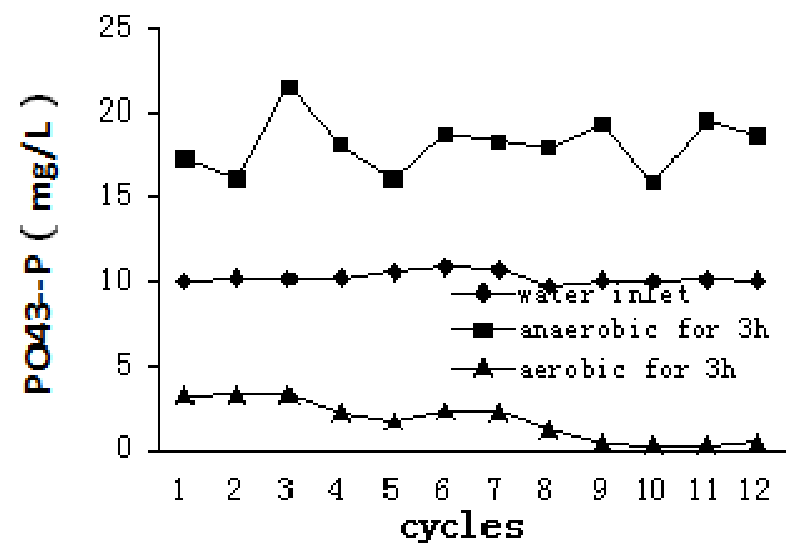

Fig. 1. The change of $\mathrm{PO}_{4}{ }^{3-}-\mathrm{P}$ concentration in the first stage

Figure 2 shows the $\mathrm{PO}^{3-}-\mathrm{P}$ removal efficiency changes. As shown in Figure 2, $\mathrm{PO}_{4}{ }^{3-}-\mathrm{P}$ concentration reduced obviously, and the $\mathrm{PO}^{3}{ }^{3}-\mathrm{P}$ removal efficiency can retain more than $95 \%$, after the enrichment of DPB in the second stage(running 40 cycles). What's more, $\mathrm{NO}_{3}{ }^{-} \mathrm{N}$ and $\mathrm{NO}_{2}{ }^{-} \mathrm{N}^{-}$can't be tested out in the wastewater, which shows that we can achieve the removal of nitrogen and phosphorus synchronously, finish the cultivation and domestication of DPB[4]. 


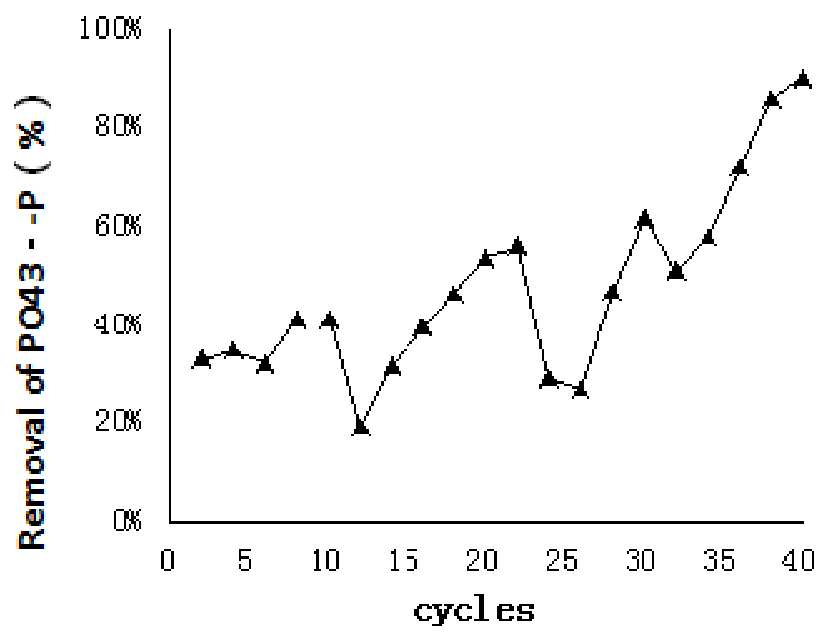

Fig.2. The removal of $\mathrm{PO}_{4}{ }^{3-}-\mathrm{P}$ in the second stage

\section{The determination of DPB}

The content of DPB in sludge were tested in the study. DPB rate in the whole PAOs was calculated according to the way that calculate the ratio of anoxic absorption rate of phosphorus and aerobic absorption rate of phosphorus, pointed by Wachtmeister[5]. Sludge fully released phosphorus was taken $1000 \mathrm{ml}$, tested out that its MLSS was 3000mg/L. Divide it in two halves equally, one absorbed phosphorus in the aerobic mode(DO $2 \mathrm{mg} / \mathrm{L}$ ), another in the anaerobic mode(DO $0.11 \mathrm{mg} / \mathrm{L}$, adding $50 \mathrm{mg} / \mathrm{L} \mathrm{NO}_{3} 7 \mathrm{~N}$ one time ), then we can get the DPB content of $94.9 \%$.

3. Stable running denitrifying denitrification and phosphorus removal performance of the system

DPB enriched effectively after the cultivation and domestication, and the system operated steadily. The system operated in anaerobic stage for $3 \mathrm{~h}$ and in anoxic stage for $4 \mathrm{~h}$. Monitor the change of $\mathrm{PO}_{4}{ }^{3}$ ${ }^{-}-\mathrm{P} 、 \mathrm{COD}$ and $\mathrm{NO}_{3}{ }^{-} \mathrm{N}$ concentration, the result were shown in figure 3.

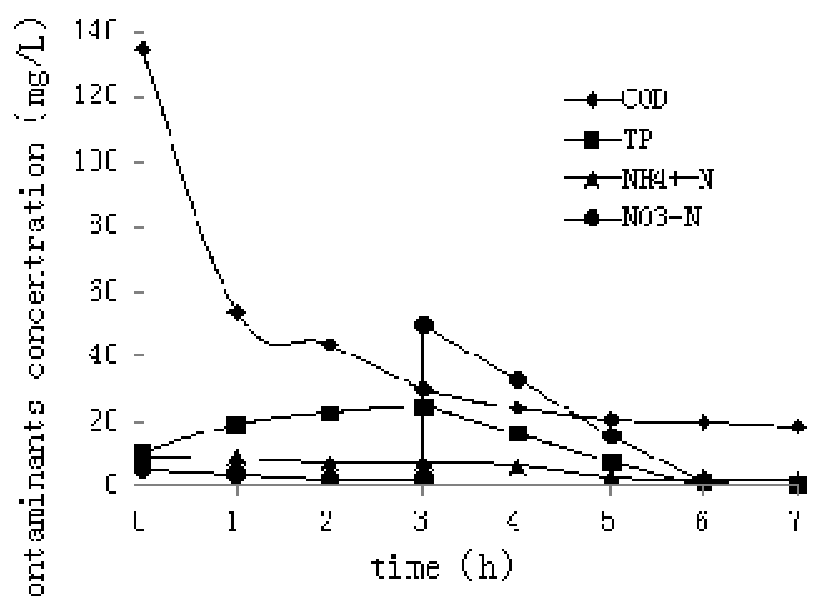

Fig.3. The removal of contaminants by a stable operation system

In anaerobic stage, COD concentration shows a rapidly declining trend, with the increase of $\mathrm{PO}_{4}{ }^{3}$ -P concentration, which shows a obvious phenomenon of release phosphorus. In the end of the anaerobic stage, the concentration was increased to $24.56 \mathrm{mg} / \mathrm{L}$. However, in the anoxic stage, the downward trend of COD concentration slowed down, while the $\mathrm{PO}_{4}{ }^{3-}$-P concentration dropped rapidly, which shows the phenomenon of Denitrifying phosphorus absorbing. After the anoxic mode(4 h), the $\mathrm{PO}_{4}{ }^{3-}-\mathrm{P}$ concentration and the $\mathrm{NO}_{3}{ }^{\mathrm{N}}$ concentration were decreased to $0.38 \mathrm{mg} / \mathrm{L}$ and 
$0.022 \mathrm{mg} / \mathrm{L}$, respectively. In the system it can reach as high as $96 \%$ phosphorus removal efficiency and 99\% nitrogen removal efficiency. From the character of Denitrifying phosphorus removal, there are mount of Denitrifying phosphorus removing bacteria in the reactive system, which can use $\mathrm{NO}_{3}{ }^{-} \mathrm{N}$ as electron acceptor, to absorb phosphorus.DPB has become the advantage bacterials in SBR system, owing to the cultivation and domestication.

\section{Conclusion}

1.After the cultivation and domestication in the two stages, DPB were enriched rapidly, what content can reach $94.9 \%$.

2. After the treatment of wastewater what has a low carbon source using steadily operating DPB, the removal rate of $\mathrm{PO}_{4}{ }^{3-}-\mathrm{P}, \mathrm{NH}_{4}{ }^{+}-\mathrm{N}$ and COD was $94 \%, 78 \%$ and $86 \%$ respectively when the effluent concentration was below $0.4 \mathrm{mg} / \mathrm{L}, 3 \mathrm{mg} / \mathrm{L}$ and $20 \mathrm{mg} / \mathrm{L}$ respectively, which indicated that enrichment and cultivation of denitrifying phosphorus removing bacteria in a set of SBR was feasible.

\section{References}

[1] Kuba T,Van Loosdrecht M C M,Heijinen J J. Phosphorus and nitrogen removal with minimal COD requirement by integration of denitrifying dephosphatation and nitrification in a two-sludge system[ $\mathrm{J}]$. Water Res,1996,30(7) : 1702-1710.

[2] Meinhold J,Filipe C D M,Daigger G T,et al. Characterization of the denitrifying fraction of phosphate accumulating organisms in biological phosphate removal[ $\mathrm{J}]$. Water Sci Technol,1999,39(1) : 31-42.

[3] Lee D S,Jeon C O,Park J M. Biological nitrogen removal with enhanced phosphate uptake in a sequencing batch reactor using single sludge system [ J ] . Water Res,2001,35 ( 16 ) : 3968-3976.

[4] Liu Jing-jing, Wang Ping,Ma Jie-feng. An aerobic denitrifier with low levels production of nitrous oxide[J]. Environmental Science\&Technology,2008,31(5):26-29.

[5] Wachtmeister A,Kuba T,Loosdrech van M C M,et al.A sludge Characterization Assay for Aerobic and Denitrifying Phosphorus Removing Sludge[J]. Wat.Res.1997,31(3):471-478. 